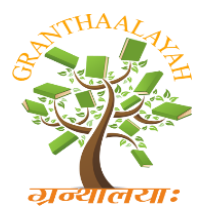

INTERNATIONAL JOURNAL OF RESEARCH -
GRANTHAALAYAH
A knowledge Repository

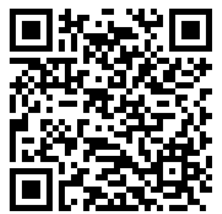

Management

\title{
IMPACT OF GLOBAL FINANCIAL CRISIS ON JAPAN, CHINA, INDIA AND USA STOCK EXCHANGE AND INTER-LINKAGE BETWEEN THEM
}

\author{
Rabia Najaf ${ }^{1}$ \\ ${ }^{1}$ Department of Accounting \& Finance, University of Lahore, Islamabad Campus, PAKISTAN
}

\begin{abstract}
In this paper, we analyzed the impact of financial crisis on different countries by the using of E-GARCH model .our main finding is that in the financial crisis has impact on the stock exchange of different countries. We proved that due to financial crisis most of countries stock exchange have been affected badly. In the world, the American stock exchange was established in 1792. Two dozen brokers were started the stock trading. Now a day, 2,429 companies are listed under this stock exchange. The prime objective of the scholars is to find out the impact of financial crisis on the different stock market. Scholars have proved that financial crisis have always impacted on the financial markets.
\end{abstract}

Keywords:

Financial Crisis, E-GARCH, Brokers, Financial Markets.

Cite This Article: Rabia Najaf, "IMPACT OF GLOBAL FINANCIAL CRISIS ON JAPAN, CHINA, INDIA AND USA STOCK EXCHANGE AND INTER-LINKAGE BETWEEN THEM" International Journal of Research - Granthaalayah, Vol. 4, No. 5 (2016): 189-197.

\section{INTRODUCTION}

Stock exchange is known as backbone of any country.in this paper, researchers are trying to prove that how financial crisis did impact of stock exchange of different countries. The phenenomen of financial crisis is common in all over the world therefore, not anybody can reject this hypothesis that stock exchange can be affected by financial crisis. Robust of the studies have been observed that there is causal Association between stock market and exchange rate. Exchange rate is crucial element for analysis the performance of the stock exchange. Stock prices have the main tool through which investors can take proper decision about the future investments. For the better investment public must be aware about the stock market prices. It is also act as the risk seeker. There are no of variables, which have influenced on the stock market performance. Exchange rate is such the shock that can block the stock market. Therefore most of the researchers take it for analysis the performance of the stock market. Exchange rate is also affected on the industries production. This thing has proved that there is negative association 
between increase exchange rate and stock market .Due to financial crisis exchange rate is affected badly and thus will effect on performance of stock returns.

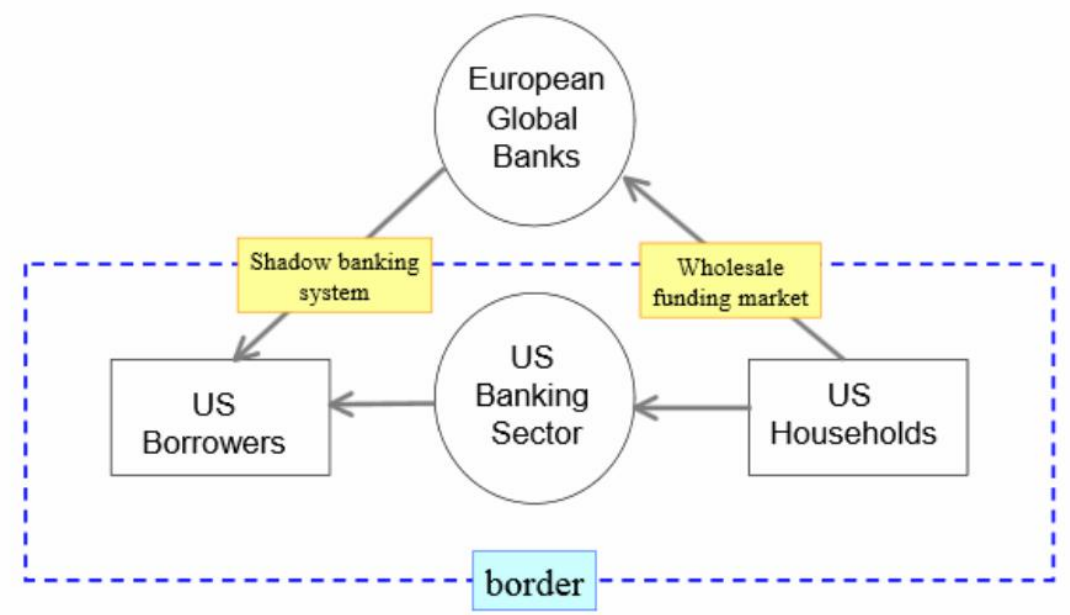

Figure 1. European global banks add intermediation capacity for connecting US savers and borrowers

\section{The cycle of market emotions}

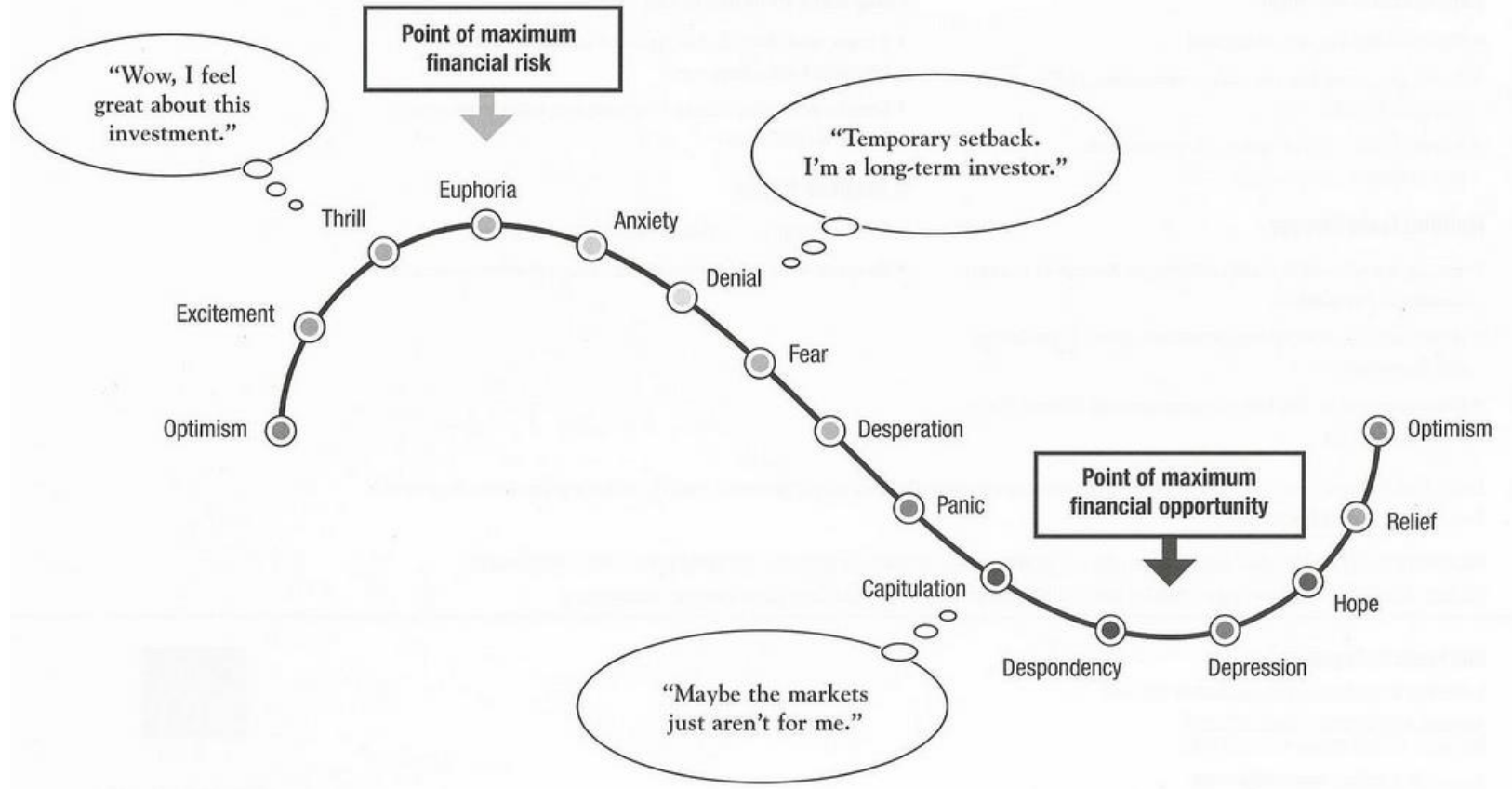

Figure 2:

\section{LITERATURE REVIEW}

There are three types of volatility which are being significant in this era. Robust of researchers have been study the different models to analysis the influence of financial crisis on the stock 
returns. Ke, wang, muray, analyzed the volatility spillover influence between Shanghai stock exchange and different stock market namely, New York, London an d Frankfurt and also did comparison between emerging countries and shanghai stock exchange through E-Garch model. Their results have shown that after the financial crisis there is bidirectional influence. This paper is also exploring that before the financial crisis the shanghai stock exchange was B shape and it had influenced on the Japan stock exchange [1].

Kim analyzed the efficiency of different stock markets and financial crisis 1997, impact on the performance of these stock markets. These studies have proved that Hong Kong was badly affected due to financial crisis [2].

Sakthivel, and Kamaiah had analyzed the independency between European and, Asian stock exchange and US market. They utilized the daily data for this purpose and applied the Johansen co integration method. This study is proving that Indian stock market was highly affected due to this financial 1 crisis [3].

Sakthival, BOdkhe, and Kamiah, observed the statistical relationship between major stock exchange .For this purpose they have utilized the Vicariate Garth model and found the results that there exist the long run co integration between them. This study is also proving that USA and Japan stock exchange had experienced the external shocks because these both stock exchanges are powerfully united due to their international trade [4].

Royfaizal, Lee, Azali, had analyzed the linkage between ASEAN countries and US stock exchange. They had applied the Granger causality test and found the result that these stock exchanges have linkage with each other [5].

Sigh, analyzed the linkage between Indian and Chinese stock market with developed countries he had utilized the daily data from period of 2000 to 2009 , he had applied the ECM and granger causality it is proving that Chinese and Indian stock exchange has correlation with the developed countries stock exchange[5].

Abidin, analyzed the asymmetric volatility in the stock exchange of New Zealand for the period of 2007-2008 .they had applied the E - Garch and T-Garch model and has shown the results that there exist the asymmetric volatility in this stock exchange [6].

Verma and Mahajan, employed the augmented E - Garch model on the stock prices of India .this study is showing that US. Financial dissolving has influenced on the Indian stock exchange [7].

Olowe, studies that volatility of the Nigeria stock returns for this purpose he had utilized the data from periods of 5 Jan 2005 to Jan 10, 2009.He had found that there is exist the high volatility and in the stock market there exists the risk return relationship [8].

\section{GAPS IN THE LITERATURE}

1) In the prior studies had not discussed about the how convergence of the stock markets reruns on the sectoral level. 
2) If there is convergence then how fast it is?

3) What is the impact of financial crisis on the integration of stock market?

4) Why China stock exchange has not any special influence and USA stock market affected very roughly.

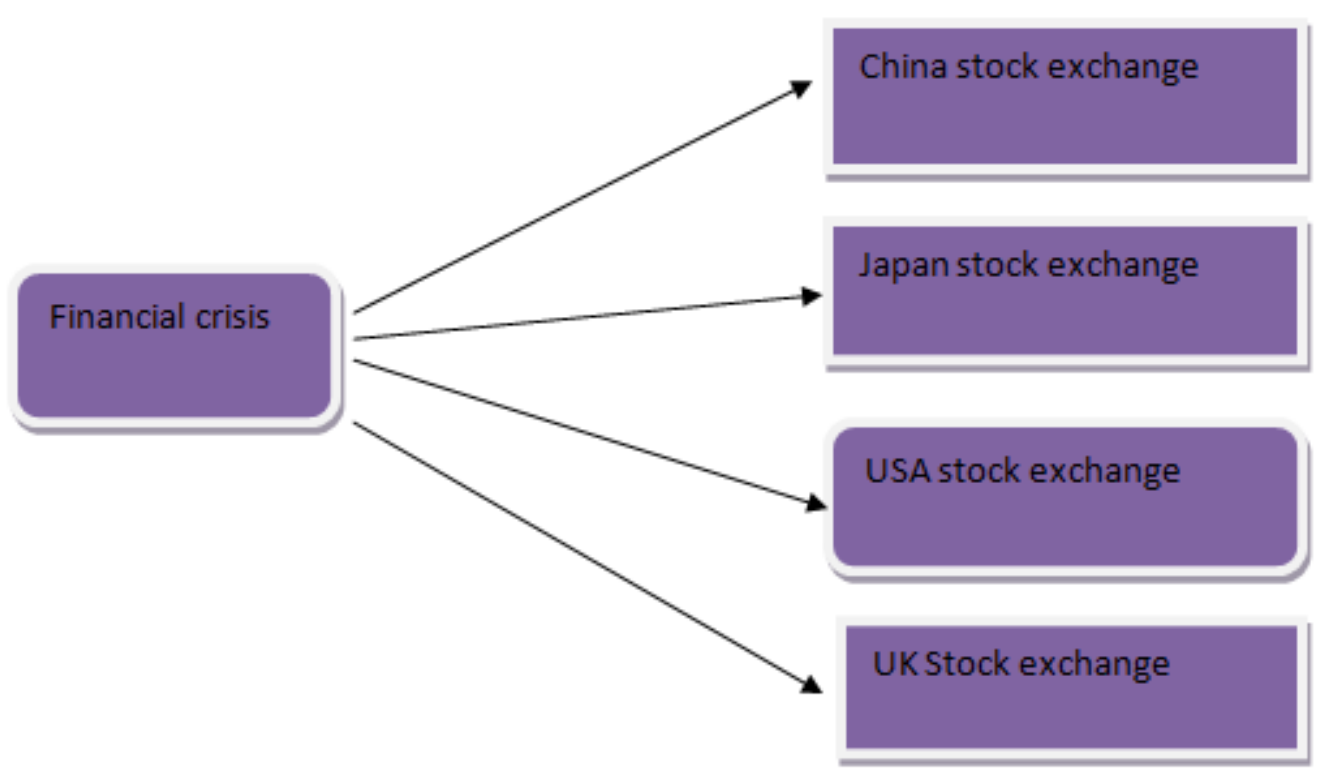

Figure 3:

\section{DATA}

Our study is based on the daily stock index closing prices of main two developed country and tan Asian emerging markets. The sample period consists of 1662 observations which is taken from Jan 2, 1995 to May, 15 2001.All stock indices are expressed in the shape of local currency and in the form of US dollar. Our source of data is data stream.

\section{CO INTEGRATION ANALYSIS RESULTS}

On the base, of Aaike information criterion we have selected the VAR model. In this research we have selected two logs. Diagnostic statistics is showing that residuals are free from autocorrelation problems. We are representation the Trace test results in table 1 and 2 respectively.

Table 1:

\begin{tabular}{|c|c|c|c|c|}
\hline & $\begin{array}{c}\text { Entire Period } \\
\left(6^{\text {th }} \text { of January, }\right. \\
2006 \\
\text { to } 22^{\text {nd }} \text { of April, } \\
2011) \\
\end{array}$ & $\begin{array}{c}\text { Period } 1 \\
\left(6^{\text {th }} \text { of January, }\right. \\
2006 \\
\text { to } 21^{\text {st }} \text { of January, } \\
2008) \\
\end{array}$ & $\begin{array}{c}\text { Period } 2 \\
\left(22^{\text {nd }} \text { of January, }\right. \\
2008 \\
\text { to } 25^{\text {th }} \text { of March, } \\
2009)\end{array}$ & $\begin{array}{c}\text { Period } 3 \\
\left(26^{\text {th }} \text { of March, }\right. \\
2009 \\
\text { to } 22^{\text {nd }} \text { of April, } \\
2011) \\
\end{array}$ \\
\hline Mean & 0.000297 & 0.001196 & -0.001124 & 0.000221 \\
\hline Median & 0.000565 & 0.001657 & -0.001028 & 0.000417 \\
\hline
\end{tabular}




\begin{tabular}{|c|c|c|c|c|}
\hline Maximum & 0.039234 & 0.022561 & 0.039236 & 0,020321 \\
\hline Minimum & -0.040196 & -0.040198 & -0.034934 & -0.030327 \\
\hline Std.Dev. & 0.008533 & 0.007896 & 0.011979 & 0.006527 \\
\hline Skewness & -0.448394 & -1.023946 & 0.180803 & -0.729034 \\
\hline Kurtosis & 5.649954 & 6.296178 & 3.878892 & 5,287908 \\
\hline $\begin{array}{l}\text { Jargue-Bera } \\
\text { (Probability) }\end{array}$ & $\begin{array}{l}438.9354 \\
(0.000000)\end{array}$ & $\begin{array}{l}321.8785 \\
(0.000000)\end{array}$ & $\begin{array}{l}11.10193 \\
(0.003885)\end{array}$ & $\begin{array}{c}164.9976 \\
(0.000000)\end{array}$ \\
\hline Observations & 1347 & 514 & 296 & 539 \\
\hline
\end{tabular}

Source: Results from Eviews-7

Table 2:

\begin{tabular}{|c|c|c|c|c|}
\hline & $\begin{array}{c}\text { Entire Period } \\
\left(^{\text {th }} \text { of January, }\right. \\
2006 \\
\text { to } 22^{\text {nd }} \text { of April, } \\
2011)\end{array}$ & $\begin{array}{c}\text { Period } 1 \\
\text { ( } 6^{\text {th }} \text { of January, } \\
2006 \\
\text { to } 21^{\text {st }} \text { of } \\
\text { January, 2008) }\end{array}$ & $\begin{array}{c}\text { Period } 2 \\
\left(22^{\text {nd }} \text { of January, }\right. \\
2008 \\
\text { to } 25^{\text {th }} \text { of March, } \\
2009)\end{array}$ & $\begin{array}{c}\text { Period } 3 \\
\left(26^{\text {th }} \text { of March, }\right. \\
2009 \\
\text { to } 22^{\text {nd }} \text { of April, } \\
2011)\end{array}$ \\
\hline Mean & 0.000233 & 0.000518 & -0.00092 & 0.000512 \\
\hline Median & 0.000543 & 0.000849 & -0.000975 & 0.000565 \\
\hline Maximum & 0.069444 & 0.028955 & 0.034313 & 0.069445 \\
\hline Minimum & -0.050396 & -0.033423 & -0.050398 & -0.026095 \\
\hline Std.Dev. & 0.008365 & 0.007087 & 0.012234 & 0.006687 \\
\hline Skewness & 0.111931 & -0.503934 & -0.084916 & 2.091369 \\
\hline Kurtosis & 8.958181 & 5.711593 & 3.695188 & 24.94131 \\
\hline $\begin{array}{l}\text { Jargue-Bera } \\
\text { (Probability) }\end{array}$ & $\begin{array}{l}1931.551 \\
(0.000000)\end{array}$ & $\begin{array}{l}176.4365 \\
(0.000000)\end{array}$ & $\begin{array}{l}6.060206 \\
(0.048312)\end{array}$ & $\begin{array}{l}10685.12 \\
(0.000000)\end{array}$ \\
\hline Observations & 1305 & 507 & 285 & 515 \\
\hline
\end{tabular}

Source: Results from Eviews-7

Table 3: Unit root test

\begin{tabular}{|l|c|c|c|}
\hline Stock return & SSE composite & BSE-30 & \multicolumn{1}{c|}{ Nikkei-225 } \\
\hline ADF statistic & $-36.69064(0.0000)$ & $-33.58153(0.0000)$ & $-37.65206(0.0000)$ \\
\hline ADF (I) & $-36.72071(0.0000)$ & $-33.59568(0.0000)$ & $-37.65731(0.0000)$ \\
\hline ADF (I\&T) & $-36.78341(0.0000)$ & $-33.58375(0.0000)$ & $-37.64318(0.0000)$ \\
\hline
\end{tabular}

Source: Results from Eviews-7

\section{Unit root test}

There is need of statistical adequacy to take the different in the time series. For this purpose we have utilized the unit root test. For checking the stationary of data we applied the ADF test. In the table no 3 and 4 have shown that there is not unit root exist between the time series all the stock return are stationary. 
Table 4: Unit root test

\begin{tabular}{|l|c|c|}
\hline \multicolumn{1}{|c|}{ Stock return } & S\&P 500 & NYSE \\
\hline ADF statistic & $-30.79142(0.0000)$ & $-31.07222(0.0000)$ \\
\hline ADF (I) & $-31.07223(0.0000)$ & $-31.06094(0.0000)$ \\
\hline ADF (I\&T) & $-30.78037(0.0000)$ & $-31.05638(0.0000)$ \\
\hline
\end{tabular}

Source: Results from Eviews-7

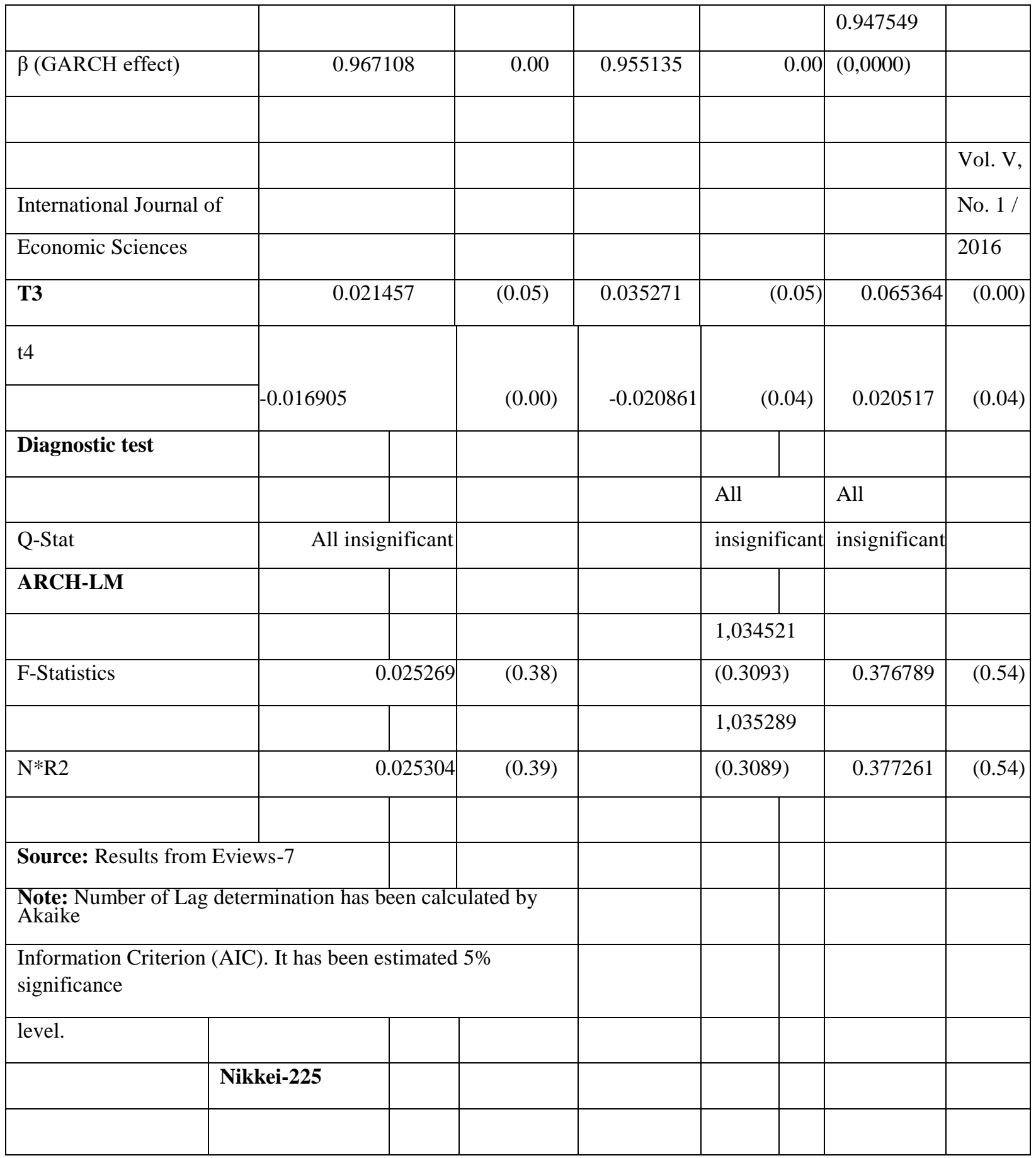




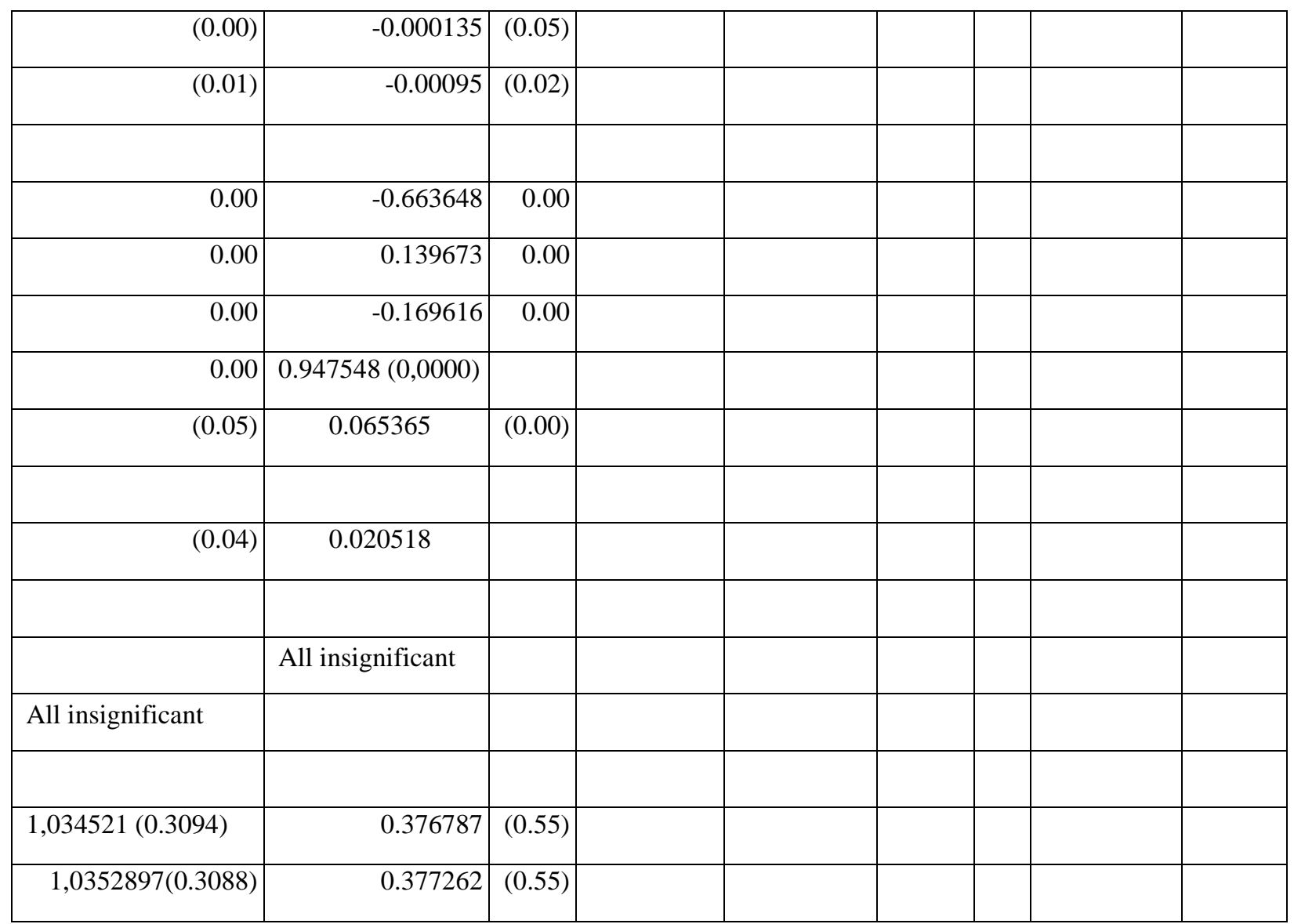

Note: Number of Lag determination has been calculated by Akaike Information Criterion (AIC). It has been estimated 5\% significance level.

Table 6: Parameter Estimates of E-GARCH model for S\&P 500 and NYSE

\section{Coefficients (Probability)}

\section{Variables}

$\begin{array}{lll} & \text { S\&P 500 } & \text { NYSE } \\ \mathrm{i} & 0.000148(0.0094) & 0.000138(0,0089) \\ a_{1} & -0.001359(0.0023) & -0.001358(0,000)\end{array}$

\section{Variance Equation}

\begin{tabular}{|c|c|c|}
\hline$\omega$ & $-0.425422(0.0000)$ & $-0.433833(0.0000)$ \\
\hline$\alpha(A R C H$ effect) & $0.084724(0.0000)$ & $0.091951(0.0000)$ \\
\hline Y (Leverage effect) & $-0.172081(0.0000)$ & $-0.182682(0.0000)$ \\
\hline$\beta$ (GARCH effect) & $0.968422(0.0000)$ & $0.968531(0.0000)$ \\
\hline - 3 & $0.070834(0.0000)$ & $0.071796(0.0000)$ \\
\hline
\end{tabular}


$0.023182(0.0000)$

Diagnostic test

Q-Stat

All insignificant

All insignificant

ARCH-LM

F-Statistics

$8.529254(0.0037)$

$8.770444(0.0032)$

$N^{*} \mathrm{R} 2$

8.487652(0.0033)

$8.726096(0.0036)$

Source: Results from Eviews-7

\section{SUGGESTION}

1) There should be proper integration of different Asian stock market with global stock market.

2) There is needed to make policy makers for this purpose.

3) USA stock exchange should do work against the financial crisis.

4) Japan also should apply some policies against such type of financial crisis.

\section{CONCLUSION}

Our results is showing that global financial crisis become the reason of decrease the stock return. Global financial crisis has become the increase the volatility of different Asian countries and volatility of stock prices of USA stock exchange. The result of EARCH model is showing that financial crisis has not more affected on the China s stock exchange as compared to other stock exchange. In the large extent global financial crisis has influences on the USA stock exchange. The results of Granger causality are showing that at the start of financial crisis the USA stock exchange has the bidirectional influenced on the Asian stock exchange. Due to USA stock exchange Japanese stock exchange receives the volatility spillover. Our paper has examined that Chinese stock exchange do not receive the volatility spillover.

\section{REFERENCES}

[1] ABIDIN, S. (2012). Is There Asymmetric Volatility in New Zealand During the Global FinancialCrisis?Availablehttp://papers.ssrn.com/sol3/papers.cfm?abstract_id=2187679h ttp://dx.doi.org/10.2139/ssrn.2187679

[2] ADAMU, A. (2010). Global financial crisis and Nigerian stock market volatility. Proceedings of the National Conference on "Managing the Challenges of Global Financial Crisis in Developing Economies”. 2010, Vol. 1, p. 102-113.

[3] ADAS, C. G. and KARTALLI, F. Y. (2014). Sudden Stops, Capital Controls and When to Apply. Journal of Faculty of Economics, Istanbul University. 2014, Vol. 65, No.1, p.1-38.

[4] ENGLE, R. (2001). GARCH 101: The Use of ARCH/GARCH Models in Applied Econometrics. Journal of Economic Perspectives. 2001, Vol.15, No.4, p.1516 http://dx.doi.org/10.1257/jep.15.4.157

[5] FORBES, K. and RIGOBON, R. (1999). No Contagion, only Interdependence: Measuring Stock Market Co-Movement. NBER Working Paper Series. 1999, No. 7267.

[6] GRANGER, C. W. J. (1969). Investigating Causal Relations by Econometric Models and Cross-spectral Methods. Econometrica. 1969, Vol. 37, No. 3, p. 424-438. http://dx.doi.org/10.2307/1912791 
[7] KARANASOS, M. and KIM, J. (2003). Moments of the ARMA-EGARCH model. Econometrics Journal. 2003, Vol. 6, p. 146-166. http://dx.doi.org/10.1111/1368423x.00104

[8] KE, J., WANG, L. and MURRAY, L. (2010). An empirical analysis of the volatility spillover effect between primary stock markets abroad and China. Journal of Chinese Economic and Business Studies. 2010, Vol. 8, No. 3, p. 315-333. http://dx.doi.org/10.1080/14765284.2010.493645

[9] LIM, K.; BROOKS, R. and KIM, J. (2008). Financial crisis and stock market efficiency: Empirical evidence from Asian countries. International Review of Financial Analysis. 2008, Vol. 17, No. 3, p. 571-591. http://dx.doi.org/10.1016/j.irfa.2007.03.001

[10] OLOWE, R. A. (2009). Stock return, volatility and the global financial crisis in an emerging market: the Nigerian case. International Review of Business Research Papers. 2009, Vol. 5, No. 4, p. 426-447.

[11] RAFAGET, A. and AFZAL, M. (2012). Impact of global financial crisis on stock markets: Evidence from Pakistan and India. E3 Journal of Business Management and Economics. 2012, Vol. 3, No. 7, p. 275-282.

[12] ROYFAIZAL, R. C.; LEE, C. And AZALI, M. (2009). ASEAN-5 + 3 and US Stock Markets Interdependence Before, During and After Asian Financial Crisis. International Journal of Economics and Finance. 2009, Vol. 1, No. 2, p. 45-54. http://dx.doi.org/10.5539/ijef.v1n2p45

[13] SAKTHIVEL, P.; BODKHE, N. and KAMAIAH, B. (2012). Correlation and Volatility Transmission across International Stock Markets: A Bivariate GARCH Analysis. International Journal of Economics and Finance. 2012, Vol. 4, No. 3, p. 253-264. http://dx.doi.org/10.5539/ijef.v4n3p253

[14] SAKTHIVEL, P. and KAMAIAH, B. (2012). Inter -linkages among Asian, European and the U.S stock markets: A Multivariate Co integration analysis. Journal of Economics and Behavioral Studies. 2012, Vol. 4, No. 3, p. 129-141.

[15] SETH, A.(2007).Granger causality 2007, 2(7):1667. http://dx.doi.org/10.4249/scholarpedia.1667

[16] SINGH, G. S. P. (2010). Chinese and Indian Stock Market Linkages with Developed Stock Markets. Asian Journal of Finance \& Accounting. 2010, Vol. 2, No. 2, p. 21-39.

[17] STERN, D. I. (2011). From Correlation to Granger Causality. Crawford School Research Paper No 13, Paper presented at the AIJOS Capstone Conference, University of Michigan, Ann Arbor MI, 29-30 September 2011. http://ssrn.com/abstract=1959624http://dx.doi.org/10.2139/ssrn.1959624

[18] SULEMAN, M. T. (2012). Stock Market Reaction to Good and Bad Political News. Asian Journal of Finance \& Accounting. 2012, Vol. 4, No. 1, p. 299-312. http://dx.doi.org/10.5296/ajfa.v4i1.1705

[19] VERMA, S. and MAHAJAN, N. (2012). Stock return, volatility and the global financial meltdown: the behavior of Indian stock market. International Journal of Arts and Commerce. 2012, Vol. 1, No. 7, p. 166-178. 